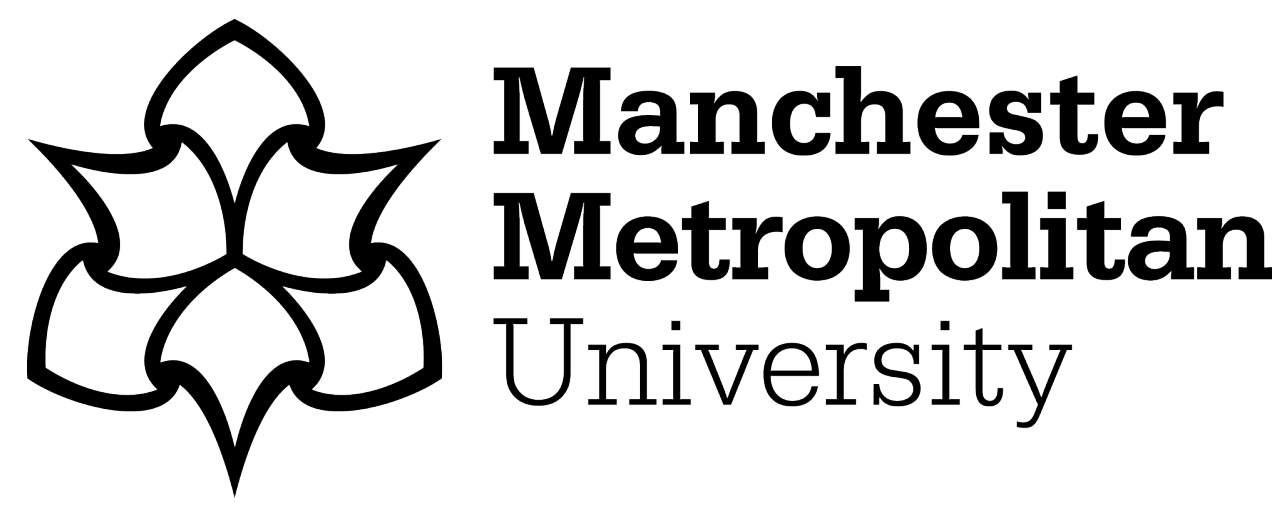

Carlin, Matthew ORCID logoORCID: https://orcid.org/0000-0002-0955-9463 (2019) Celestin Freinet: The Printing Press and Student Work. In: Encyclopedia of Educational Innovation. Springer. ISBN 978-981-13-2262-4

Downloaded from: https://e-space.mmu.ac.uk/622091/

Version: Accepted Version

Publisher: Springer

DOI: https://doi.org/10.1007/978-981-13-2262-4_159-1

Please cite the published version 


\section{Matthew Carlin}

Senior Lecturer, Manchester Metropolitan University

m.carlin@mmu.ac.uk

Celestin Freinet: The Printing Press and Student Work

Encyclopedia of Educational Innovation

Work, Society and Education

\section{Introduction}

The progressive movement of education that began in the late 19th Century in various parts of the world was developed in reaction to the problems and limitations that many teachers and philosophers identified in traditional forms of formal education in both the US and Europe at the time. There are many names that are commonly associated with progressive education or the 'new education movement' including Johann Pestalozzi, Colonel Francis Parker, Maria Montessori, Adolph Freierere, Ovide Decroly, John Dewey, and Rudolf Steiner, among others. In spite of their theoretical differences, all of these figures were, in one way or another, responding to the authoritarian, top-down and overly didactic style inherent to classical approaches to pedagogy that had existed up until that point, by situating the experiences of the child as the focal point of their approach to pedagogy. One other name that often (although not always) appears on this list is Celestin Freinet (1896-1966). Like many of the seminal figures of 'the new education movement',' Freinet developed a number of concepts that demonstrated a similar commitment to a 'child-centred approach' to teaching and learning. For example, Freinet spoke of 'centres of interest' that refers to utilising the interest of children as a means to develop educational activities. He also prioritized 'enquiry based learning' that understands learning as primarily taking place experimentally through the natural inductive processes of children. He also discussed what he called 'cooperative learning' that emphasized the importance of collective over individual forms of student learning. Finally, Freinet also spoke of 'the pedagogy of work,' that refers to how learning takes place through the collective, and autonomous work of students. It is this concept that is the focus of this entry and also that which helps to explain why his name is not always 
mentioned in the same breathe as those theorists commonly associated with progressive education. We begin with a brief biographical sketch of Celestin's journey into the teaching profession, followed by an overview of his use of the printing press as a means to transform the social dynamics of the classroom and situate work as the primary learning activity of both teachers and students alike.

\section{Path to Teaching}

Celestin Freinet was born at the base of the French Alps in the small, rural farming community of Gars, France in 1896. Like many families in Gars, the Freinet's made their living as sheep farmers. According to his wife Elise Freinet, it was Celestin's time spent as a shepherd in his youth that served as "the leitmotiv" of his own early educational experiences. Although he always described his time as a shepherd in positive terms, his formal educational experiences were less so. In his primary and secondary schooling, Celestin often struggled to succeed under the authoritarian pedagogical methods that were typically employed in French schools during the early part of the 20th Century. The combination of his disappointing experiences in formal schooling and his family's financial burdens, caused Celestin to drop out of school before finishing his secondary education. His withdrawal from the school system prior to graduating from secondary school also eliminated him from consideration for study at a university.

Although Freinet's experiences as a young student in Gars were anything but optimal, they nevertheless provoked him to take an interest in the teaching profession in the hopes of better understanding how schools improve their approach to pedagogy. Fortunately, due to the fact that France offered up the possibility of pursuing a career in teaching without having to attend university, Celestin was able to move forward with the formal study of his interests in teaching and learning. As a result, Freinet was eventually able to enrol in a teachers 
training program in Nice. Almost immediately after gaining his teaching certificate, however, his professional ambitions had to be postponed as a result of the outbreak of WWI as he was called to enlist in the French Army.

Despite having to postpone his career ambitions as a teacher, Freinet's eventual work as an educator would undergo profound transformations thanks in large part to his experiences in the war. According to his wife, Elise Freinet (1968), Freinet's teaching philosophy is directly attributable to his experiences as a soldier when he sustained a serious lung injury during a poison gas attack. As the story is often told, after from the war Freinet discovered that the wound to his lungs would preclude him from approach his teaching of primary and secondary students as a traditional lecturer. As Freinet (1970) explains,

"(W)hen I returned from the great war in 1920, I wasn't the same due to a glorious wound in my lung that weakened and exhausted me to the extent that I was incapable of speaking in my class for more than a few minutes at a time. ...If I had had, like all of my other colleagues, sufficiently strong breath to dominate the passivity of my students with my voice, I would have been convinced that my technique, in spite of everything, was acceptable. I would've continued to utilize saliva, the number one instrument of what we call traditional school, and as a result my experiences (as a teacher) would've come to an end" (p.11).

As a consequence of his "glorious wound," Freinet was incapable delivering formal educational content through the traditional means of long, didactically structured lectures. As a result, if Freinet was to continue his career in the teaching profession he realized he would have to find a new approach to working with his students. 
After close to four years recovering in various hospitals in France after suffering the injury, Freinet became healthy enough to begin to officially pursue his work as a teacher. His first position he aquired was in a small, rural town in southern France called Le Bar--SurLoup that was located among the Alps near the Mediterranean sea. Shortly after being hired, Freinet became a member of the anarcho-syndicalist teachers union, and began engaging with and discussing many of the anti-authoritarian and child-centred pedagogical theories emerging out of the "New Education Movement." It is certainly reasonable to assume that Freinet's reading of some of the seminal figures associated with New Education Movement had influenced his own work and approach to teaching and learning. However, Freinet's own writings ( ), which included few citations, never explicitly describes the way that other educational innovators of the time influenced his own thought.

It was the combination of his new corporeal limitations and the political and social transformations that were moving across Europe at the time that incited him to rethink the best way to interact with his students, organise his classroom, and develop his curriculum. As a result, Freinet extracted himself as the focal point of the delivery of the curriculum and replaced the podium behind which he was to lecture, with a printing press.

In many ways, Freinet's printing press has come to take on a kind of mythological status as the primary example of his pedagogical genius. However, Freinet deserves no such credit. At the very least we know that Polish pedagogue Janusz Korczak utilized the printing press in order to work with his students to create a student journal as early as 1921 . This in no way diminishes Freinet's innovations. The introduction of the press was never the most notable development in his pedagogical approach. Instead, what is genuinely novel about Freinet's use of the printing press was the way he placed it in such a prominent position within the classroom and the corresponding way that student work was initiated and developed as a result. 
Placing the printing press in the centre of classroom was the first action by Freinet that transformed the way that students began to learn. As a disruption to the organizational structure of the class itself, the printing press replaced the platform and lecturer as the hub of student work. Students ceased to be organised in a way that reflected a strict hierarchical relationship between themselves and the teacher, and instead participated in the creation of a collective form of social organization that pivoted around both the maintenance and use of the press in the production of written texts. The podium was no longer central. In fact the podium was often utilised in Freinet's classroom as a storage space for school files. Moreover, the strict unidirectional organization of desks into lines was eroded, and even the teacher's physical position in the classroom was reduced to the level of a student desk, becoming just one among many others situated around the press.

It is important to note, however, that these radical transformations in the classroom did not reflect a commitment on Freinet's part to either dissolve the authority of the teacher or to eliminate discipline from the classroom itself. Freinet (1990) argued that"... true discipline is not instituted from outside, according to a pre-established rule, with its procession of prohibitions and sanctions." Instead, for Freinet, discipline"... is the natural result of cooperative work and the moral climate of the class (p.35). So the question becomes how did Freinet create the kind of classroom environment conducive to the development of student work and a corresponding moral order that reflected a commitment to their work as well as one another?

The first order of cooperative work centred around learning to take care of the printing press. By collectively learning how to operate and maintain the press, students were then able to begin to utilise the press as a means to print and circulate their own work. It was the printing of student texts and subsequent circulation of these texts to neighbouring towns that served as as their second order of cooperative work. The student texts, knows as 'free 
texts' were first written by students by hand in journals. These texts were personal accounts of events that were happening in their own lives as well as in their broader community. Often, as a way to instigate student writing, Freinet organised walks with his students in the community as a way for them to begin to observe and detail what was going on around them, documenting seasonal changes as well as the work and activities that were taking place in the community.

Once the students produced a text of their own choosing they were asked to read their writing aloud in the classroom. This kind of reading was what Freinet called "work oriented reading" that identifies the way that the production and reading of the texts was a form of student work while also often being a description of the work and life of people who lived in their community with them. After each child was given the opportunity to read their own texts, the students jointly chose the best texts from their class to include as part of their newspaper. These newspapers were then printed and sent off as part of 'interscholastic exchanges' to other schools and communities. While it is true that the production of these texts was intended to help students improve their practical reading, writing, and speaking skills, the overall intention was to foment a kind of collaborative engagement with their school work, their local community, and with nearby schools. It was this introduction of the printing press into the classroom, its subsequent placement at the centre of the class, and the production of students texts that began what we now refer to as the "Freinetian Method." It was this method, that eventually gave rise to a national education movement in France.

It is important to note that the focus on the student use of the press and the collaborative production of written texts was not the only examples by which the concept of work had been re-conceptualized as an integral part of Freinet's approach to teaching and learning. There were also new ways that teachers began to participate in their own forms of cooperative work as a result of Freinet's innovation that helped establish his method as the 
collective creation of a genuine workers education. Specifically, in the early 1930's those who began to utilize the printing press and associated ideas of 'free writing' created both a public school co-operative and a journal called the 'Proletarian Educator' that served as resources for teachers around France. Among other things, this teachers' cooperative published a range of booklets based on student research called the 'library of work' that included a wealth of information on various topics compiled by students in other parts of the country that was designed to both assist teachers in their own curriculum development, as well as other students who were in developing their own research and writing projects.

Through the power to utilise the machine while producing and circulating their own writing, student work attains a new importance. Student learning is no longer focused on the individual achievement nor on the procurement of specific skills and knowledge related to future monetary gain. Rather, the work of both students and teachers in a Freinet classroom are oriented toward the development of an entire way of life focused on cooperation and a growing knowledge of the local that signifies a rejection of both the progressivist model of contemporary life.

Through the displacement of the lecturer's platform by the printing press, Freinet's method provides educators and students with the opportunity to participate in a different kind of learning. By prioritizing the maintenance and running of a machine in the production of student writing, Freinet's model of learning ceases to depend on pre-established ideological formations, and instead comes to rely on the cooperative activity of students. Freinet's once characterised the process by which the student came to appropriate both the space of the classroom and the press as 'giving the children the word.' For Freinet's, this term refers to the fact that student commitment to learning does not arise out of providing them with prefabricated terminology focused on justice, liberation, or empowerment, but rather by way of 
providing them with an opportunity within the classroom to create their own social worlds and work.

\section{$\underline{\text { Conclusion }}$}

Freinet's use of the printing press as a way to restructure the classroom and incorporate productive, useful work as the focal point of student directed learning, places Freinet in a unique place among his peers in the new education movement of the 19th and 20th Centuries. While, his own writings (few of which have been translated into English) remain underappreciated chiefly due to his non-academic, and non-philosophical writing style, his lack of recognition is also due to the way that he conceptualized student freedom in a way that was unrestricted by an underlying ideology, and at odds with the progressivism inherent to both Marxist and liberal approaches to pedagogy. Instead of utilizing work in the classroom as a way to engage his students in the entreprenuerial free play coveted by the global, capitalist market place, Freinet created an environment conducive to the emergence of a form of disciplined, cooperative and autonomous student work. It is this aspect of his approach to teaching and learning that perhaps makes his work more relevant today than it was during his own time.

References:

Celestin Freinet

1970 Technicas Freinet de La Escuela Moderna. Siglo Veintiuno Editores: Mexico, DF.

1990 Cooperative Learning and Social Change: Selected Writings of Celestin Freinet. trans. and ed. David Clanfield \& John Sivell. Ontario Institute for Studies in Education Publishing: Toronto, Ontario. 
1990 The Wisdom of Matthew: An Essay in Contemporary French Educational Theory. E. Mellen: Lewiston, NY.

1993 Education through work: a model for child centered learning, trans. John Sivell Edwin Mellen Press: Lewiston, NY.

1994 Euvres pédagogiques, 2 volumes. Edited by Madeleine Bens-Freinet, introduction par Jacques Bens. Seuil: Paris. 